\title{
Effect of Paullinia cupana on MCF-7 breast cancer cell response to chemotherapeutic drugs
}

\author{
EVERALDO HERTZ ${ }^{1}$, FRANCINE CARLA CADONÁ ${ }^{2}$, ALENCAR KOLINSKI MACHADO ${ }^{1}$, \\ VERÔNICA AZZOLIN $^{1}$, SABRINA HOLMRICH ${ }^{2}$, CHARLES ASSMANN $^{3}$, PAULINE LEDUR ${ }^{1}$, \\ EULER ESTEVES RIBEIRO ${ }^{4}$, OLMIRO CEZIMBRA DE SOUZA FILHO ${ }^{1,3}$, \\ MARIA FERNANDA MÂNICA-CATTANI ${ }^{2,3}$ and IVANA BEATRICE MÂNICA DA CRUZ ${ }^{1-3}$ \\ ${ }^{1}$ Postgraduate Program in Pharmacology, Center of Health Sciences; \\ ${ }^{2}$ Postgraduate Program in Biochemistry and Toxicology, Center of Natural and Exact Sciences; \\ ${ }^{3}$ Laboratory of Biogenomics, Center of Health Sciences, Federal University of Santa Maria, \\ Santa Maria, Rio Grande do Sul 97105-900; ${ }^{4}$ Open University of the Third Age, \\ State University of Amazonas, Manaus, Amazonas 69050-900, Brazil
}

Received May 6, 2014; Accepted September 10, 2014

DOI: $10.3892 / \mathrm{mco} .2014 .438$

\begin{abstract}
Previous studies suggested that certain plants, such as guarana (Paullinia cupana), exert a protective effect against cancer-related fatigue in breast cancer patients undergoing chemotherapy. However, guarana possesses bioactive molecules, such as caffeine and catechin, which may affect the pharmacological properties of antitumor drugs. Therefore, the aim of this study was to evaluate the effects of guarana on breast cancer cell response to 7 chemotherapeutic agents currently used in the treatment of breast cancer. To perform this study, MCF-7 breast cancer cells were cultured under controlled conditions and exposed to 1,5 and $10 \mu \mathrm{g} / \mathrm{ml}$ guarana concentrations, with and without chemotherapeutics (gemcitabine, vinorelbine, methotrexate, 5-fluorouracil, paclitaxel, doxorubicin and cyclophosphamide). The effect of these treatments on MCF-7 cell viability and proliferation was spectrophotometrically analyzed with the MTT assay. The main results demonstrated an antiproliferative effect of guarana at concentrations of 5 and $10 \mu \mathrm{g} / \mathrm{ml}$ and a significant effect on chemotherapeutic drug action. In general, guarana improved the antiproliferative effect of chemotherapeutic agents, causing a decrease of $>40 \%$ in cell growth after $72 \mathrm{~h}$ of exposure. The results suggested an interaction of guarana with
\end{abstract}

Correspondence to: Professor Ivana Beatrice Mânica da Cruz, Laboratory of Biogenomics, Center of Health Sciences, Federal University of Santa Maria, 1000 Roraima Avenue, Building 19, Santa Maria, Rio Grande do Sul 97105-900, Brazil

E-mail: ibmcruz@hotmail.com

Key words: guarana, antitumor, chemotherapy, breast cancer, fatigue the chemotherapeutic drugs, which requires confirmation by in vivo complementary studies.

\section{Introduction}

Cancer-related fatigue (CRF) is a common phenomenon in patients undergoing cytotoxic chemotherapy and radiotherapy, with a prevalence of 59-100\%, depending on the clinical status of the disease (1). CRF is also associated with other physical and psychological symptoms, such as pain, sleep disturbance, reduced physical activity and depression $(2,3)$. Therefore, CRF negatively affects the functional status and quality of life of the patients (4).

Patients exhibiting moderate or severe fatigue may benefit from non-pharmacological as well as pharmacological interventions, including use of psychostimulants, such as methylphenidate and dexmethylphenidate, modafinil and erythropoietin-stimulating agents (5). However, the clinical management of CRF remains unsatisfactory. For this reason, de Oliveira Campos et al (6) performed a phase II randomized, double-blind, placebo-controlled crossover study to evaluated the effect of guarana (Paullinia cupana) against CRF. Guarana is an Amazon fruit used since the pre-Columbian era that is currently commercialized in herbal and energetic beverages due to its stimulant properties (7).

A phase II randomized, double-blind, placebo-controlled crossover study was conducted by de Oliveira Campos et al (6) on breast cancer patients undergoing systemic chemotherapy, with $100 \mathrm{mg} /$ day of guarana powder supplementation. The guarana supplementation significantly decreased CRF. The study also reported no occurrence of toxic adverse effects, sleep disturbance or anxiety and depression in the patients receiving guarana supplementation. For this reason, the authors suggested that guarana may be an effective, non-toxic, cost-effective option for the treatment of CRF (6). A complementary study was also recently published, demonstrating that a purified dry extract of guarana may be effective in treating 
CRF patients with various solid tumors who undergo chemotherapy (8).

The guarana effect on CRF is possibly associated with its chemical composition, which includes a higher content of purinic alkaloid caffeine (1,3,7-trimethylxanthine) compared to coffee (Coffea arabica), tea (Camellia sinensis) and yerba mate (Ilex paraguariensis). Guarana also contains a small proportion of other purinic alkaloids, including theobromine and theophylline (6), as well as other chemical bioactive molecules, such as tannins and proanthocyanidins, with a higher content of catechins and epicatechins (9).

Despite the results suggesting a beneficial effect of guarana on breast cancer patients with $\mathrm{CRF}$, the bioactive molecules in guarana may also affect the chemotherapeutic efficacy. The potential antitumor effect of catechins on breast cancer cells has being extensively described in the literature $(10,11)$. However, the effect of caffeine is more controversial (12). A previous study suggested that caffeine may attenuate the MCF-7 cell response to chemotherapy due its ability to intercalate into DNA (13). By contrast, another study performed on MCF-7 breast cancer cells treated with paclitaxel reported that caffeine supplementation enhanced the apoptosis induction triggered by the chemotherapeutic drug (14). A recent study also demonstrated that co-treatment with anticancer agents and 6-selenocaffeine decreased MCF-7 cell viability (15).

The abovementioned evidence prompted us to investigate whether guarana affects the properties of antitumor drugs when concomitantly administered to MCF-7 breast cancer cells. Therefore, the present study aimed to evaluate the effect of guarana on MCF-7 cell viability and proliferation, with and without exposure to 7 chemotherapeutic agents currently used in the treatment of breast cancer.

\section{Materials and methods}

Chemicals. Analytical grade chemicals and reagents were obtained from Sigma-Aldrich (St. Louis, MO, USA). The MCF-7 cell line was obtained from American Type Culture Collection (Manassas, VA, USA). The RPMI-1640 culture medium, fetal bovine serum (FBS), heat-inactivated equine serum, penicillin and streptomycin were purchased from Gibco (Grand Island, NY, USA); Vacutainer ${ }^{\circledR}$ tubes were provided by BD Diagnostics (Plymouth, UK).

Guarana extract. The guarana powder used in the present study was supplied by Western Agropecuary Research Brazilian Enterprise (EMBRAPA), a non-profit Brazilian governmental sector that offers technical support to the production of guarana in the Amazonas state. The bioactive compounds present in guarana powder were previously determined and described (16). The extract contained $12.240 \mathrm{mg} / \mathrm{g}$ caffeine, $6.733 \mathrm{mg} / \mathrm{g}$ theobromine and $4.336 \mathrm{mg} / \mathrm{g}$ total catechins. The concentration of condensed tannin was $16 \mathrm{mg} / \mathrm{g}$. To perform the in vitro assay, the lyophilized extract was diluted in distilled water to a concentration of $200 \mathrm{mg} / \mathrm{ml}$. The mixture was infused for $7 \mathrm{~min}$ by boiling, centrifuged at $1,500 \mathrm{x} \mathrm{g}$ for $15 \mathrm{~min}$ and filtered. The solution was sterilized by filtration $(0.20 \mu \mathrm{M})$, diluted in distilled water and added to cell culture medium to obtain 1,5 and $10 \mu \mathrm{g} / \mathrm{ml}$ guarana concentrations. These concentrations were selected considering that in vivo guarana supplementation of breast cancer patients was relatively lower (100 mg/day).

Cell culture. MCF-7 cells were cultured in Dulbecco's modified Eagle's medium supplemented with $10 \%$ FBS, $2 \mathrm{mM}$ L-glutamine, $1 \mathrm{mM}$ sodium pyruvate, $0.1 \mathrm{mM}$ non-essential amino acids, $100 \mathrm{U} / \mathrm{ml}$ penicillin and $100 \mathrm{~g} / \mathrm{ml}$ streptomycin $\left(\mathrm{pH} \mathrm{7.2)}\right.$ in a $5 \% \mathrm{CO}_{2}$ incubator at $37^{\circ} \mathrm{C}$. Cell viability was measured using the MTT cell proliferation assay (17). Cells $\left(1 \times 10^{5}\right)$ were seeded in a 96 -well plate in $200 \mu \mathrm{l}$ complete culture medium. Following overnight adhesion, the medium was changed with media containing the antitumor drugs and different guarana extract concentrations. All the experiments were performed in triplicate.

Antitumor and guarana co-administration. The effect of the three different guarana concentrations on the cytotoxic and antiproliferative properties of 7 antitumor agents currently used in the treatment of breast cancer were tested on MCF-7 cells. The main actions of the chemotherapeutic agents on the cell cycle are presented in Fig. 1.

The selection of the antitumor agents was based on previous studies demonstrating their cytotoxic effect on MCF-7 breast cancer cells: Cyclophosphamide, a nitrogen mustard alkylating agent that forms irreversible DNA crosslinks leading to cell death (18); doxorubicin, an anthracycline antibiotic with a DNA intercalating effect; 5-fluorouracil, a pyrimidine analog that belongs to the family of antimetabolite drugs, causing irreversible inhibition of thymidylate synthase and, consequently, cell cycle arrest and apoptosis (19); paclitaxel, a mitotic inhibitor targeting tubulin, causing defects in mitotic spindle assembly and chromosome segregation (20); vinorelbine, a semi-synthetic vinca alkaloid with an antimitotic effect (21); gemcitabine, a nucleoside analog that adds a 'faulty' nucleoside during DNA synthesis, leading to cell apoptosis (22); and methotrexate, a folic acid analogue that prevents purine and pyrimidine synthesis, leading to the inhibition of DNA, RNA and protein synthesis (23). Based on previous studies investigating the effects of these chemotherapeutics on MCF-7 cells, their concentrations were as follows: $10 \mu \mathrm{M}$ gemcitabine (22), vinorelbine and methotrexate (24); $2 \mu \mathrm{M}$ 5-fluorouracil (25); $50 \mu \mathrm{M}$ paclitaxel (26); $200 \mathrm{nM}$ doxorubicin (19); and $5 \mathrm{mM}$ cyclophosphamide (27).

Cell viability and proliferation analysis. To evaluate the effect of the co-administration of guarana and antitumor agents on cell viability and proliferation, the MTT assay was used as previously described by Fukui et al (26), who investigated the effect of resveratrol and paclitaxel co-administration on the viability of several cancer cell lines with slight modifications. A total of $10 \mu \mathrm{l}$ of MTT (at $5 \mathrm{mg} / \mathrm{ml}$ ) was added to each well at a final concentration of $500 \mu \mathrm{g} / \mathrm{ml}$. Subsequently, the mixture in each well was incubated for $1 \mathrm{~h}$. The MTT is reduced by mitochondrial dehydrogenase in living cells to produce insoluble purple formazan crystals that are quantitatively measured following their removal from the cells by the addition of $100 \mu \mathrm{l}$ dimethyl sulfoxide (DMSO) (18). However, prior to the addition of DMSO, the treatment samples in the 96-well plate were visualized by optic microscopy (magnification, $\mathrm{x} 400$ ) and photographed. The images displayed living cells with purple 


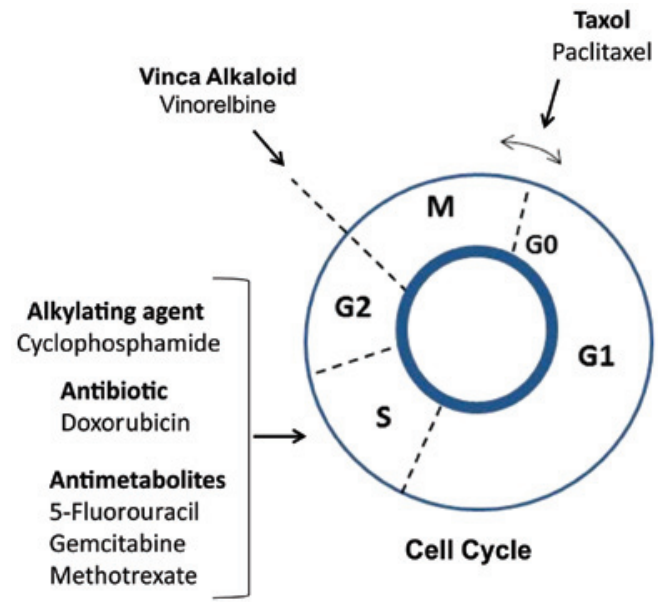

Figure 1. Chemotherapeutic agents used in the treatment of breast cancer and their action on the cell cycle.

formazan crystals and dying cells without crystals. The absorbance was read at $560 \mathrm{~nm}$. The relative cell viability and/or proliferation under antitumor agent and guarana treatment were expressed as a percentage of the control well that was not treated with chemotherapeutic drugs. To evaluate the guarana co-administration effect on the properties of the chemotherapeutic agents, the results were expressed as a percentage of each tumor agent without guarana addition. All the experiments were performed in triplicate.

Statistical analysis. The different treatments were compared using one-way analysis of variance followed by Tukey's post hoc test. All the tests with $\mathrm{P}<0.05$ were considered to indicate statistically significant differences.

\section{Results}

Effect of chemotherapeutic agents on cell viability and proliferation. The effect of the chemotherapeutics on MCF-7 cells was initially determined to confirm that their concentrations were effective in decreasing cell viability and proliferation (Fig. 2). As expected, all the investigated drugs significantly decreased MCF-7 cell viability and proliferation $(\mathrm{P}<0.01)$. The effect on viability was similar among all the chemotherapeutic agents used in the present study. However, the effect on cell proliferation was drug-dependent. Paclitaxel and cyclophosphamide were the chemotherapeutics that most significantly inhibited MCF-7 cell proliferation ( $>70 \%$ ) compared to the control untreated cells and the cells treated by the other 5 agents.

Effect of guarana on cell viability and proliferation. The guarana extract produced from toasted seeds used in all the protocols exhibited a high caffeine content $(12.3 \mathrm{mg} / \mathrm{g})$ and was also rich in theobromine $(6.8 \mathrm{mg} / \mathrm{g})$ and total catechins (4.3 mg/g) (Fig. 3A and B). Therefore, three low concentrations of guarana $(1,5$ and $10 \mu \mathrm{g} / \mathrm{ml})$ were selected to investigate the effect of this extract on antitumor drugs. The isolated effect of guarana was evaluated prior to testing its action on MCF-7 cell response to chemotherapeutic drugs. As can be seen in Fig. 3, the three guarana concentrations tested here did not affect MCF-7 cell viability at $24 \mathrm{~h}$ of exposure. However, a signifi- cant effect on MCF-7 cell proliferation was observed in the cells exposed to guarana at concentrations of 5 and $10 \mu \mathrm{g} / \mathrm{ml}$ $(\mathrm{P}<0.01)$.

Effect of guarana on the action of chemotherapeutic agents. Based on these data, the effect of guarana on the action of chemotherapeutics in MCF-7 cells was finally evaluated and the results are presented in Figs. 4 and 5. Guarana did not affect the viability of MCF-7 cells treated with cyclophosphamide, gemcitabine and paclitaxel after $24 \mathrm{~h}$ of exposure (Fig. 4A-C). However, the presence of different guarana concentrations significantly increased the cytotoxicity of 5-fluorouracil after $24 \mathrm{~h}$ of exposure. 5-Fluorouracil plus guarana at concentrations of 5 or $10 \mu \mathrm{g} / \mathrm{ml}$ killed $~ 50 \%$ of the MCF-7 cells compared to the untreated control group (Fig. 4D).

By contrast, when compared to the negative and positive control groups, guarana significantly increased MCF-7 cell viability in the methotrexate- (Fig. 5A), doxorubicin- (Fig. 5B) and vinorelbine-treated groups (Fig. 5C), mainly at concentrations of 5 and $10 \mu \mathrm{g} / \mathrm{ml}$.

Different from the results at $24 \mathrm{~h}$, the combination of guarana with all the investigated chemotherapeutic drugs exerted a strong antiproliferative effect on MCF-7 cells after $72 \mathrm{~h}$ of exposure $(\mathrm{P}<0.01)$. This effect was more prominent when the cells were exposed to all guarana concentrations and paclitaxel. The cell proliferation was reduced by $\sim 80 \%$ when compared to the untreated control group. Furthermore, cyclophosphamide plus guarana at $5 \mu \mathrm{g} / \mathrm{ml}$ was also effective in decreasing the MCF-7 cell population by $>80 \%$ compared to the control group (Fig. 4A). As regards the other antitumor drugs, the presence of guarana inhibited cell proliferation by $\sim 40-50 \%$ when compared to the negative control group.

\section{Discussion}

Historically, natural products have provided resources for the development of several antitumor molecules. Plants, marine organisms and microorganisms are the origin of $>60 \%$ of the drugs currently used in cancer therapy (28). In addition, plants may also be used to treat adverse effects caused by chemotherapeutics, such as CRF. However, this effect has being less extensively investigated compared to the anticancer action.

The present study demonstrated that guarana at low concentrations is able to differentially modulate MCF-7 cell proliferation, as well as affect the antitumor properties of 7 chemotherapeutic agents currently used in the treatment of breast cancer. In general, guarana intensified the antiproliferative effects of all the investigated drugs, although the initial effect on cell viability was heterogeneous.

Guarana possesses biological properties described in the literature as anti-inflammatory (29), antidepressant (30), panicolytic (31) and energetic (6), which may help minimize CRF, as previously reported $(7,8)$. Other studies have also described the antitumor activity of guarana using animal and cell experimental models (32-34). It has been suggested that guarana may be used to improve CRF caused by chemotherapy, which prompted us to conduct the present study.

Considering that guarana is rich in caffeine and also contains catechins, we performed a literature review regarding the potential effect of caffeine and catechins on MCF-7 cells, 


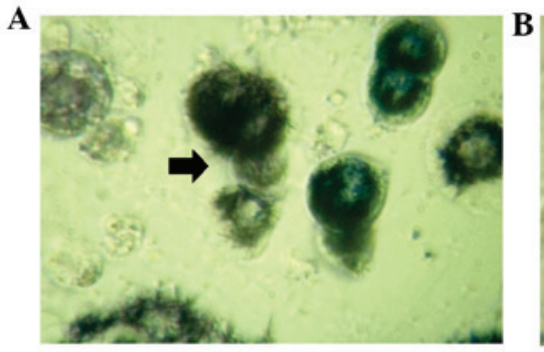

C
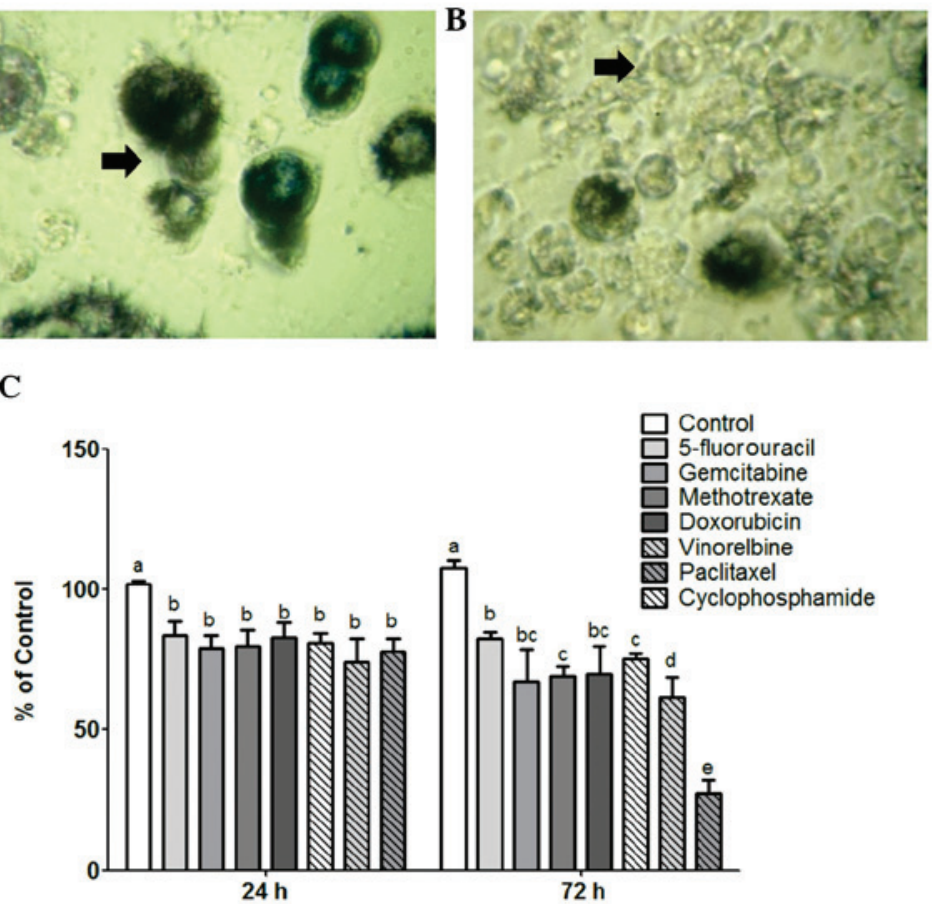

Figure 2. Chemotherapeutics effect on MCF-7 cell viability ( $24 \mathrm{~h}$ ) and proliferation (72 h). (A) Microphotography of untreated viable MCF-7 cells showing the reaction with MTT that produces formazan, an insoluble crystal of purple color (arrow). (B) Microphotography of dying MCF-7 cells exposed to paclitaxel, exhibiting a lower formazan content. (C) Viability and proliferation of MCF-7 cells exposed to several chemotherapeutic drugs (data presented as \% of control group). Different letters indicate statistically significant differences at $\mathrm{P}<0.05$ among untreated MCF-7 cells and cells treated with different chemotherapic drugs determined by one-way analysis of variance followed by Tukey's post hoc test.
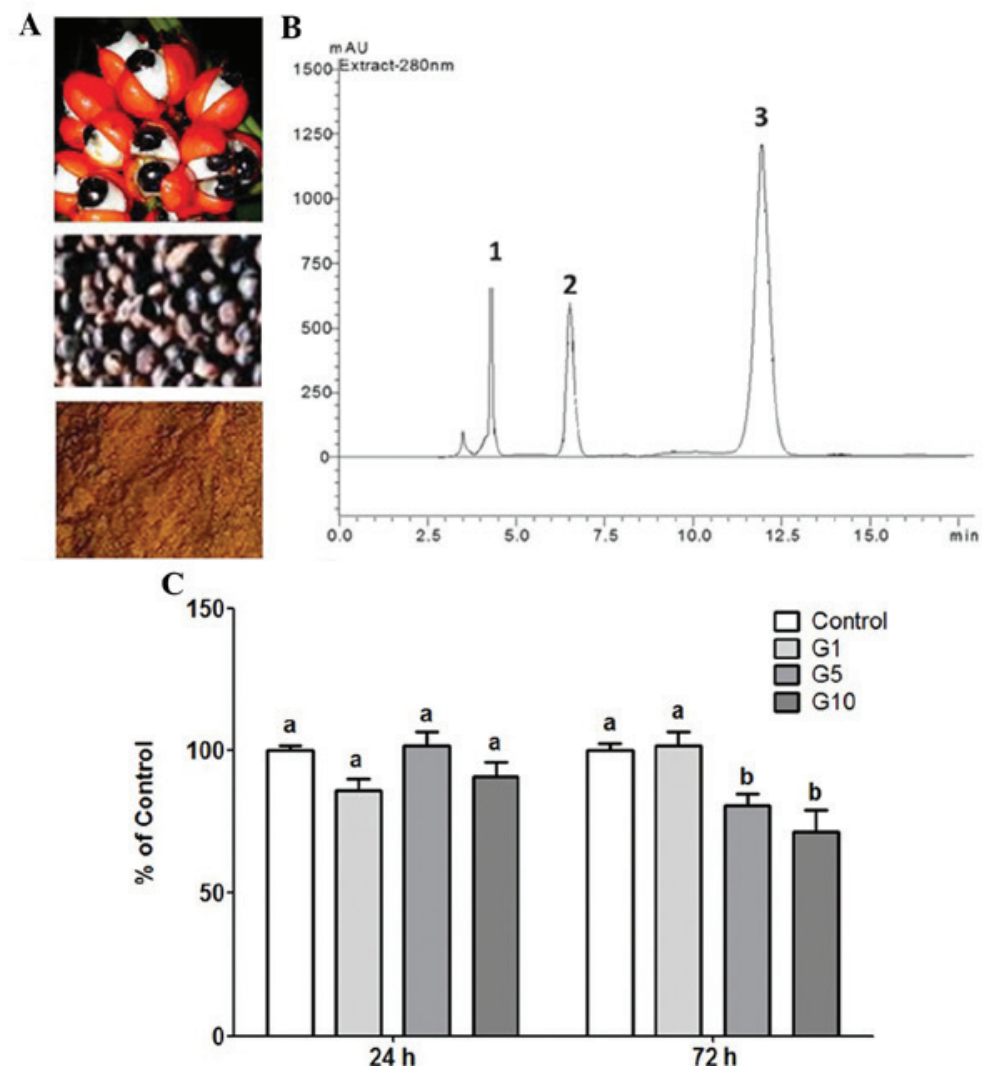

Figure 3. Effect of guarana on MCF-7 breast cancer cells. (A) Guarana powder is produced from toasted and triturated seeds. (B) Chromatography of guarana hydro-alcoholic extract exhibiting three peaks: 1, theobromine; 2, catechins; and 3, caffeine. (C) Effect of guarana at different concentrations (1, 5 and $10 \mu \mathrm{g} / \mathrm{ml}$ ) on MCF-7 cell viability (measured after $24 \mathrm{~h}$ of exposure) and proliferation (measured after $72 \mathrm{~h}$ of exposure). Different letters indicate statistical differences at $\mathrm{P}<0.05$ among untreated MCF-7 cells and cells treated with different guaraná extract concentrations determined by one-way analysis of variance followed by Tukey's post hoc test. 

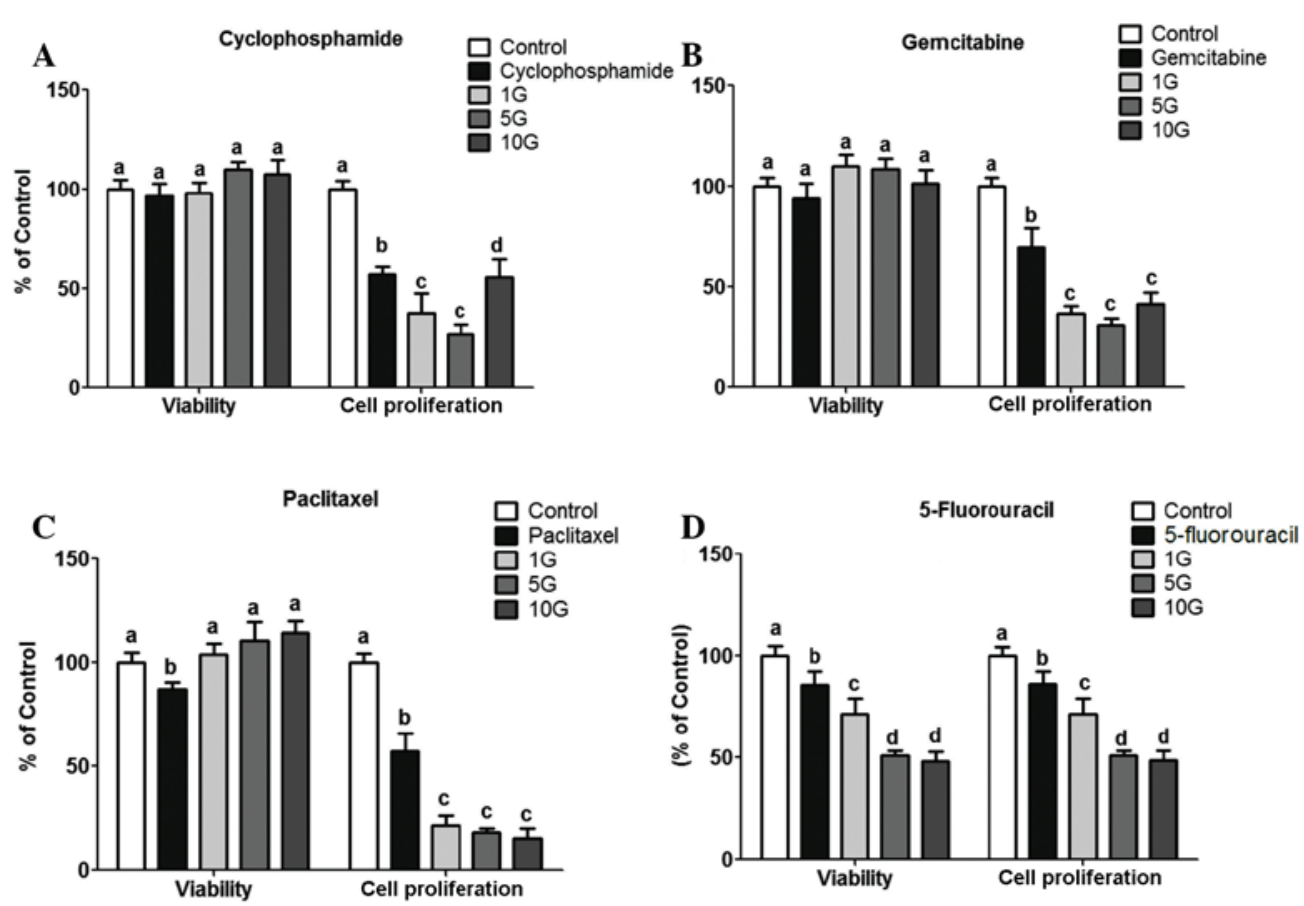

Figure 4. Effect of guarana on antitumor activity in MCF-7 cells exposed to different chemotherapeutics. Guarana concentrations: $1 \mathrm{G}, 1 \mu \mathrm{g} / \mathrm{ml} ; 5 \mathrm{G}, 5 \mu \mathrm{g} / \mathrm{ml}$; and $10 \mathrm{G}, 10 \mu \mathrm{g} / \mathrm{ml}$. Different letters indicate statistically significant differences at $\mathrm{P}<0.05$ among untreated MCF-7 cells and cells treated with different guaraná extract concentrations plus chemotherapic drugs determined by one-way analysis of variance followed by Tukey's post hoc test.
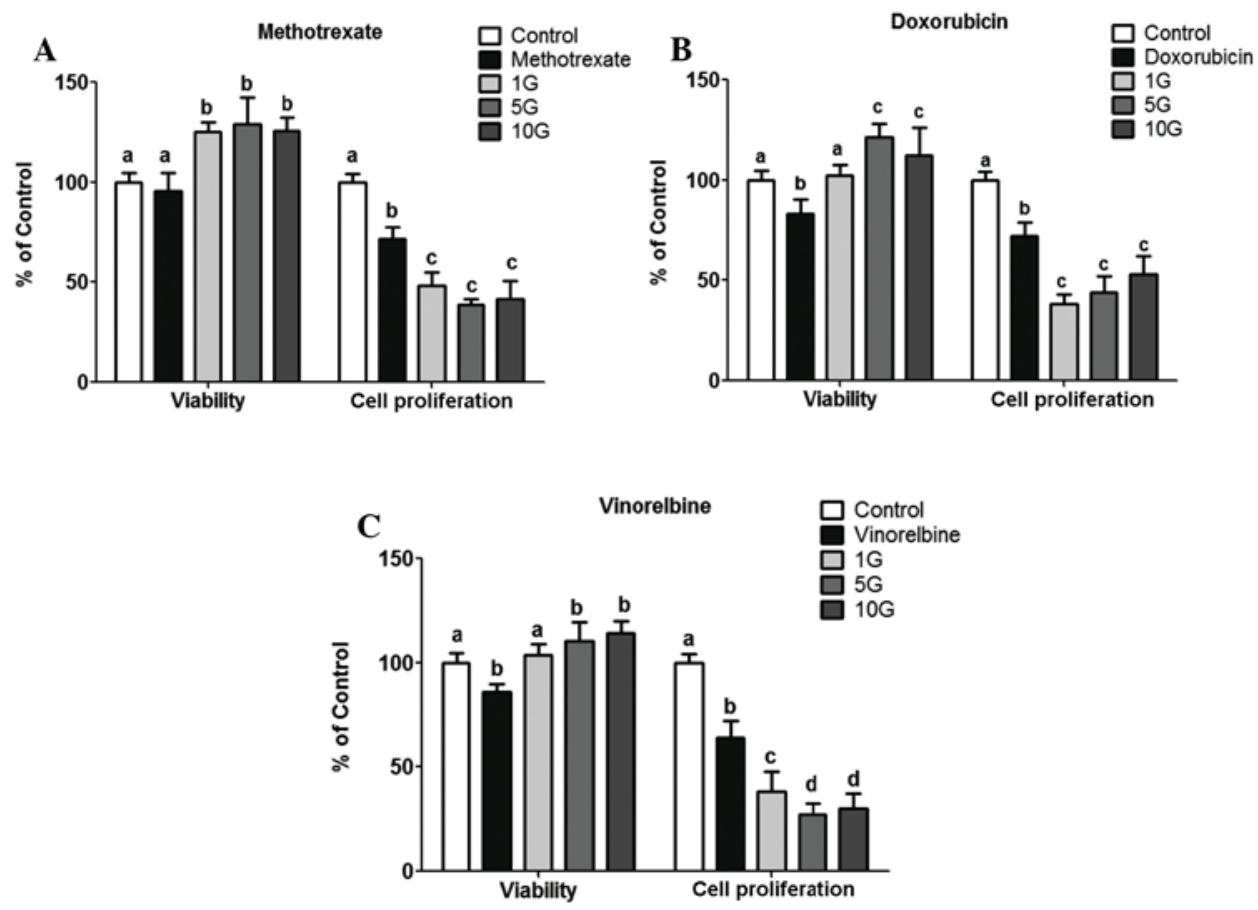

Figure 5. Effect of guarana on antitumor activity in MCF-7 cells exposed to different chemotherapeutics. Guarana concentrations: $1 \mathrm{G}, 1 \mu \mathrm{g} / \mathrm{ml} ; 5 \mathrm{G}, 5 \mu \mathrm{g} / \mathrm{ml}$; and 10G, $10 \mu \mathrm{g} / \mathrm{ml}$. Different letters indicate statistically significant differences at $\mathrm{P}<0.05$ among untreated MCF-7 cells and cells treated with different guaraná extract concentrations plus chemotherapic drugs determined by one-way analysis of variance followed by Tukey's post hoc test.

as well as the effect of these molecules on cell response to antitumor drugs.

MCF-7 is a cell line derived from an invasive ductal breast carcinoma, which expresses estrogen and progesterone receptors and exhibits a proliferative response in the presence of progesterone. This cell line may be used to investigate resistance to antitumor agents, involving overexpression of the ABCG2 protein that confers multidrug resistance to tumor cells by extruding a variety of chemotherapeutic agents (35). Caffeine, the most widely used neuroactive compound in the human diet, has antiproliferative activity and the ability to induce cell cycle arrest and apoptosis (10). 
However, the effect of caffeine on antitumor drugs appears to be cell line- and drug-dependent. As regards MCF-7, the line used in the present study, previous studies demonstrated the effect of caffeine on enhancing cell apoptosis caused by exposure to paclitaxel (14) and increasing the cytotoxic effect of alkylating drugs, such as cyclophosphamide (36). In addition, caffeine and other xanthines, including theophylline and dyphylline, significantly decreased the expression of the ABCG2 protein in the MCF-7/MX100 subline, which exhibits a high resistance to anti-breast cancer drugs (37).

By contrast, Hill et al (13) reported that caffeine may attenuate the cytotoxic effect of intercalating antitumor drugs, such as doxorubicin. That study described a possible interceptor role of caffeine, protecting cancer cell DNA from intercalation. In the present study, we observed a significant increase in MCF-7 cell viability after $24 \mathrm{~h}$ of exposure to doxorubicin plus guarana at concentrations of 5 and $10 \mu \mathrm{g} / \mathrm{ml}$. However, this potential procarcinogenic effect was significantly attenuated after $72 \mathrm{~h}$ of exposure. This contradictory effect may be caused by other bioactive molecules present in guarana, such as catechins.

A previous study performed by Seeram et al (38) described that several catechin and anthocyanin molecules are able to inhibit the proliferation of cancer cells, including the MCF-7 cell line (39). The effect of catechins appears to be associated with the ability of these molecules to increase the expression of pro-apoptotic genes, such as caspase-3, -8, -9, as well as other genes involved in the apoptotic pathway (39).

A similar study that specifically evaluated the effect of epigallocatechin-3-gallate (EGCG), the main catechin present in green tea, on a breast carcinoma cell line resistant to tamoxifen (MCF-7Tam cells) reported cell growth inhibition and dose-dependent apoptosis. Following exposure to $100 \mu \mathrm{g} / \mathrm{ml}$ EGCG for $24 \mathrm{~h}$, the expression of Bax was increased and the expression of Bcl-2 was decreased (40). A recent study also reported that microRNA expression in MCF-7 cells may be affected by green tea, which is rich in catechins and caffeine, resulting in inhibition of carcinogenesis (41). A recent study also reported that microRNA overexpression in MCF-7 cells may be decreased following treatment with polyphenon-60, a catechin included in green tea (41). This mechanism of action may explain the antitumor effect of these molecules on MCF-7 breast cancer cells.

Despite the evidence on the effect of catechins on MCF-7 cells, we were unable to identify previous studies investigating the effect of these molecules on antitumor drug efficacy. Therefore, a complementary investigation is required to evaluate whether guarana exerts an effect on chemotherapeutic drug action associated with the effect of catechins on apoptosis and antitumor gene modulation.

Since all the investigated chemotherapeutic drugs were affected by the addition of guarana, mostly by improving the antiproliferative activity after $72 \mathrm{~h}$ of exposure, the therapeutic use of guarana in the treatment of CRF apparently does not compromise the effect of chemotherapy. However, in vitro protocols present with methodological limitations that require consideration in the interpretations of the results. Complementary in vitro investigations evaluating the gene modulation of the metabolic routes involved in carcinogenesis, as well as studies using animal models are required to verify our results.

\section{References}

1. Weiss J: Cancer-related fatigue: prevalence, assessment and treatment strategies. Expert Rev Pharmacoecon Outcomes Res 11: 441-446, 2011.

2. Byar KL, Berger AM, Bakken SL, et al: Impact of adjuvant breast cancer chemotherapy on fatigue, other symptoms, and quality of life. Oncol Nurs Forum 33: E18-E26, 2006.

3. de Jong N, Courtens AM, Abu-Saad HH, et al: Fatigue in patients with breast cancer receiving adjuvant chemotherapy: a review of the literature. Cancer Nurs 25: 283-297, 2002.

4. Saligan LN and Kim HS: A systematic review of the association between immunogenomic markers and cancer-related fatigue. Brain Behav Immun 26: 830-848, 2012.

5. Campos MP, Hassan BJ, Riechelmann R and Del Giglio A: Cancer-related fatigue: a review. Rev Assoc Med Bras 57: 211-219, 2011.

6. de Oliveira Campos MP, Riechelmann R, Martins LC, Hassan BJ, Casa FB and Del Giglio A: Guarana (Paullinia cupana) improves fatigue in breast cancer patients undergoing systemic chemotherapy. J Altern Complement Med 17: 505-512, 2011.

7. Schimpl FC, da Silva JF, Gonçalves JF and Mazzafera P: Guaraná: revisiting a highly caffeinated plant from the Amazon. J Ethnopharmacol 150: 14-31, 2013.

8. del Giglio AB, Cubero Dde I, Lerner TG, Guariento RT, de Azevedo RG, Paiva H, Goldman C, Carelli B, Cruz FM, Schindler F, Pianowski L, de Matos LL and del Giglio A: Purified dry extract of Paullinia cupana (guaraná) (PC-18) for chemotherapy-related fatigue in patients with solid tumors: an early discontinuation study. J Diet Suppl 10: 325-334, 2013.

9. Basile A, Ferrara L, Pezzo MD, Mele G, Sorbo S, Bassi P and Montesano D: Antibacterial and antioxidant activities of ethanol extract from Paullinia cupana Mart. J Ethnopharmacol 102: 32-36, 2005.

10. Valcic S, Timmermann BN, Alberts DS, Wächter GA, Krutzsch M, Wymer J and Guillén JM: Inhibitory effect of six green tea catechins and caffeine on the growth of four selected human tumor cell lines. Anticancer Drugs 7: 461-468, 1996.

11. Wu AH and Butler LM: Green tea and breast cancer. Mol Nutr Food Res 55: 921-930, 2011.

12. Jiang W, Wu Y and Jiang X: Coffee and caffeine intake and breast cancer risk: an updated dose-response meta-analysis of 37 published studies. Gynecol Oncol 129: 620-629, 2013.

13. Hill GM, Moriarity DM and Setzer WN: Attenuation of cytotoxic natural product DNA intercalating agents by caffeine. Sci Pharm 79: 729-747, 2011.

14. Saunders DE, Lawrence WD, Christensen C, Wappler NL, Ruan H and Deppe G: Paclitaxel-induced apoptosis in MCF-7 breast-cancer cells. Int J Cancer 70: 214-220, 1997.

15. Martins IL, Miranda JP, Oliveira NG, Fernandes AS, Gonçalves S and Antunes AM: Synthesis and biological activity of 6-selenocaffeine: potential modulator of chemotherapeutic drugs in breast cancer cells. Molecules 18: 5251-5264, 2013.

16. Bittencourt LS, Machado DC, Machado MM, et al: The protective effects of guaraná extract (Paullinia cupana) on fibroblast NIH-3T3 cells exposed to sodium nitroprusside. Food Chem Toxicol 53: 119-125, 2013.

17. Mosmann T: Rapid colorimetric assay for cellular growth and survival: application to proliferation and cytoxicity assays. J Immunol Methods 65: 55-63, 1983.

18. Trebunova M, Laputkova G, Slaba E, Lacjakova K and Verebova A: Effects of docetaxel, doxorubicin and cyclophosphamide on human breast cancer cell line MCF-7. Anticancer Res 32: 2849-2854, 2012.

19. Major PP, Egan EM, Sargent L and Kufe DW: Modulation of 5-FU metabolism in human MCF-7 breast carcinoma cells. Cancer Chemother Pharmacol 8: 87-91, 1982.

20. Matsuoka H, Furusawa M, Tomoda H and Seo Y: Difference in cytotoxicity of paclitaxel against neoplastic and normal cells. Anticancer Res 14: 163-167, 1994.

21. Sugiyama K, Shimizu M, Akiyama T, Ishida H, Okabe M, Tamaoki T and Akinaga S: Combined effect of navelbine with medroxyprogesterone acetate against human breast carcinoma MCF-7 cells in vitro. Br J Cancer 77: 1737-1743, 1998.

22. Zeybek ND, Inan S, Ekerbicer N, Vatansever HS, Karakaya J and Muftuoglu SF: The effects of gemcitabine and vinorelbine on inducible nitric oxide synthase (iNOS) and endothelial nitric oxide synthase (eNOS) distribution of MCF-7 breast cancer cells. Acta Histochem 113: 62-67, 2011. 
23. Barros S, Mencia N, Rodríguez L, Oleaga C, Santos C, Noé V and Ciudad CJ: The redox state of cytochrome $c$ modulates resistance to methotrexate in human MCF7 breast cancer cells. PLoS One 8: e63276, 2013.

24. Hattangadi DK, DeMasters GA, Walker TD, Jones KR, Di X, Newsham IF and Gewirtz DA: Influence of p53 and caspase 3 activity on cell death and senescence in response to methotrexate in the breast tumor cell. Biochem Pharmacol 68: 1699-1708, 2004.

25. Patterson AV, Zhang H, Moghaddam A, Bicknell R, Talbot DC, Stratford IJ and Harris AL: Increased sensitivity to the prodrug 5'-deoxy-5-fluorouridine and modulation of 5-fluoro-2'-deoxyuridine sensitivity in MCF-7 cells transfected with thymidine phosphorylase. Br J Cancer 72: 669-675, 1995.

26. Fukui M, Yamabe $\mathrm{N}$ and Zhu BT: Resveratrol attenuates the anticancer efficacy of paclitaxel in human breast cancer cells in vitro and in vivo. Eur J Cancer 46: 1882-1891, 2010.

27. Singh N, Nigam M, Ranjan V, et al: Resveratrol as an adjunct therapy in cyclophosphamide-treated MCF-7 cells and breast tumor explants. Cancer Sci 102: 1059-1067, 2011.

28. Cragg GM and Newman DJ: Plants as a source of anti-cancer agents. J Ethnopharmacol 100: 72-79, 2005.

29. Campos AR, Barros AI, Santos FA and Rao VS: Guaraná (Paullinia cupana Mart.) offers protection against gastric lesions induced by ethanol and indomethacin in rats. Phytother Res 17 1199-1202, 2003.

30. Otobone FJ, Sanches AC, Nagae R, Martins JV, Sela VR, de Mello JC and Audi EA: Effect of lyophilized extracts from guaraná seeds [Paullinia cupana var. sorbilis (Mart.) Ducke] on behavioral profiles in rats. Phytother Res 21: 531-535, 2007.

31. Roncon CM, Biesdorf de Almeida C, Klein T, de Mello JC and Audi EA: Anxiolytic effects of a semipurified constituent of guaraná seeds on rats in the elevated T-maze test. Planta Med 77: 236-241, 2011

32. Fukumasu H, Latorre AO and Zaidan-Dagli ML: Paullinia cupana Mart. var. sorbilis, guarana, increases survival of Ehrlich ascites carcinoma (EAC) bearing mice by decreasing cyclin-D1 expression and inducing a G0/G1 cell cycle arrest in EAC cells. Phytother Res 25: 11-16, 2011.
33. Fukumasu H, Avanzo JL, Nagamine MK, Barbuto JA, Rao KV and Dagli ML: Paullinia cupana Mart var. sorbilis, guaraná, reduces cell proliferation and increases apoptosis of B16/F10 melanoma lung metastases in mice. Braz J Med Biol Res 41: 305-310, 2008

34. Fukumasu H, da Silva TC, Avanzo JL, et al: Chemopreventive effects of Paullinia cupana Mart var. sorbilis, the guaraná, on mouse hepatocarcinogenesis. Cancer Lett 233: 158-164, 2006.

35. Ifergan I, Shafran A, Jansen G, Hooijberg JH, Scheffer GL and Assaraf YG: Folate deprivation results in the loss of breast cancer resistance protein (BCRP/ABCG2) expression. A role for BCRP in cellular folate homeostasis. J Biol Chem 279: 25527-25534, 2004.

36. Teicher BA, Holden SA, Herman TS, Epelbaum R, Pardee AB and Dezube B: Efficacy of pentoxifylline as a modulator of alkylating agent activity in vitro and in vivo. Anticancer Res 11: 1555-1560, 1991.

37. Ding R, Shi J, Pabon K and Scotto KW: Xanthines down-regulate the drug transporter $\mathrm{ABCG} 2$ and reverse multidrug resistance. Mol Pharmacol 81: 328-337, 2012.

38. Seeram NP, Zhang Y and Nair MG: Inhibition of proliferation of human cancer cells and cyclooxygenase enzymes by anthocyanidins and catechins. Nutr Cancer 46: 101-106, 2003.

39. Alshatwi AA: Catechin hydrate suppresses MCF-7 proliferation through TP53/caspase-mediated apoptosis. J Exp Clin Cancer Res 29: 167, 2010.

40. Farabegoli F, Papi A, Bartolini G, Ostan R and Orlandi M: (-)-Epigallocatechin-3-gallate downregulates Pg-P and BCRP in a tamoxifen resistant MCF-7 cell line. Phytomedicine 17: 356-362, 2010

41. Fix LN, Shah M, Efferth T, Farwell MA and Zhang B: MicroRNA expression profile of MCF-7 human breast cancer cells and the effect of green tea polyphenon-60. Cancer Genomics Proteomics 7: 261-277, 2010. 